\title{
TEST RESEARCH ON SEISMIC PERFORMANCE OF STORY-ADDING FRAME STRUCTURE
}

\author{
Ding Hongyan, Guo Yaohua, Du Chuang, Zhang Lei, Zhang Puyang
}

Original scientific paper

This paper conducts comparative experiments between reinforced concrete story-adding structure and the lightweight steel story-adding method. Quasistatic test research and a comparison and analysis of the experimental results are also performed for both reinforced concrete story-adding framework and light steel story-adding under the same working conditions. The results showed that although both structural frameworks do meet seismic construction requirements to some degree, the results of experimentation reflect distinct advantages and disadvantages for both methods. Results further indicate the applicability and relevant problems requiring attention for both story-adding methods.

Keywords: concrete frame; lightweight steel story-adding; quasi-static testing; reinforced concrete story-adding; seismic performance

Ispitivanje seizmičkog ponašanja konstrukcije nosača dodatnog kata

U radu se opisuju usporedni eksperimenti između metode za dodatnu konstrukciju kata od armiranog betona i one od lakog čelika. Ispitivanje kvazistatičkog testa te usporedba i analiza eksperimentalnih rezultata također su provedeni i za okvir dodatne konstrukcije od armiranog betona kao i za onaj od lakog čelika pri istim radnim uvjetima. Rezultati su pokazali da iako obije konstrukcije okvira donekle zadovoljavaju seizmičke zahtjeve, postoje i jasne prednosti i nedostaci u obije metode. Rezultati dalje ukazuju i primjenjivost i relevantne probleme na koje je potrebno usmjeriti pozornost za obije metode dodatka kata.

Ključne riječi: betonski okvir; dodatak kata od armiranog betona; dodatak kata od lakog čelika; kvazi-statičko ispitivanje; seizmičko ponašanje

\section{Introduction}

The complex process of adding stories to existing buildings has been researched and developed at length in recent years [1, 4]. Many previous researchers have performed software simulation analyses to better understand the process of adding stories to structural frames [5, 6, 7], but computer simulation without experimental data or information from real-life engineering practice is not particularly reliable.

The most common current methods of story-adding use either concrete reinforcing bars, or steel $[2,3,13]$. These methods are largely successful, but a significant problem yet exists in determining the effects of storyadding on the seismic properties of an entire structure, a highly crucial consideration.

The integrity of the resultant addition is favourable, but the considerable increase in weight makes the seismic effects somewhat unclear. Reinforcing bars can be planted specifically to ensure they are fully anchored, but this typically results in damage to the original steel and concrete structures caused by the drilling process. These weakened joints are likely to reduce the seismic performance of the overall structure.

Story-adding using direct application of light steel is another method of transforming existing buildings, which possesses the distinct advantages of brief installation time, high degree of industrialization, convenient maintenance, and cost-effectiveness [13]. The joint is the primary element in the structural design, as it ensures effective load transformation and improves overall anti-seismic capability [14]. Column bracing effectively increases structural lateral stiffness. Though the relative displacement angle increases along with story height, it eventually evens out to where the bottom story is as stable as the rest of the structure. As the damping ratio in the steel structure increases, interlaminar shear, axial force, and relative displacement angle all decrease $[15,16]$.
In this study, the seismic performance and design methods of story-adding methods were explored at length through cyclic loading tests using both traditional plantedbar joints and lightweight steel, to obtain framework failure modes, bearing capacity, energy dissipation capacity, and other relevant parameters.

\section{Test prototype}

The test prototype used here is at the centre of a community in Hebei province, China. The original old building is a two-story reinforced concrete frame structure. The community centre's floor plan is shown in Fig. 1.

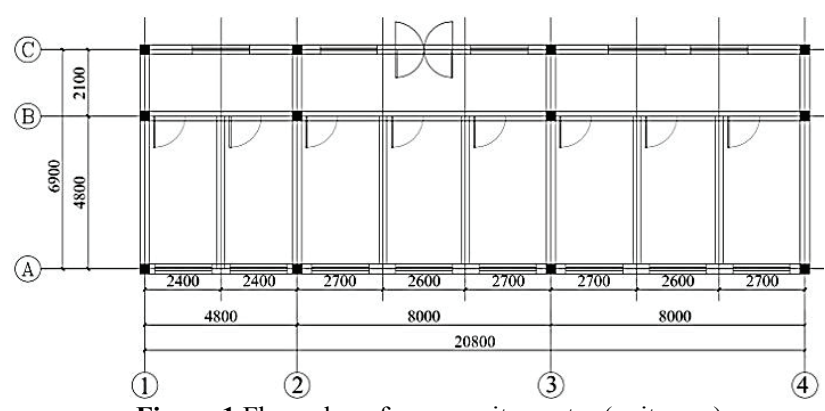

Figure 1 Floor plan of community center (unit: $\mathrm{mm}$ )

The security grade of the building structure is secondary, its seismic fortification intensity is 7 degrees, the structure's design life is 50 years, its seismic measure class is 3, its classification of seismic protection is $\mathrm{C}$, its basic design acceleration of ground motion $0,1 \mathrm{~g}$, and its classification of foundation is site II, non-liquefied. The beam and column longitudinal reinforcement used in the project was HRB400, the beams and columns stirrups were HPB300, and the concrete grade was C30. 


\section{Experimental procedure}

\subsection{Model of test design}

Small-scale testing is generally favourable, because it is faster and less expensive than large-scale or full-scale experiments [25]. For reduced-scale experiments to be reliable, however, the model must respond the same way as its prototype. To achieve this, geometric, kinematic, and dynamic relationships must be held constant. While geometric similarity is evident, kinematic and dynamic similarity are not always so [26].

To eliminate, or at least minimize, scale-effects when conducting model-scale work, the dimensional homogeneity or similitude processes were pioneered by Buckingham [27]. To accommodate the same behaviour in both prototype structure (p) and scaled model (m), material selection is predicated upon the similarity concept. Scale factors are computed using the following equation:

$S i=\frac{i \text { quantity in a scaled mondle }}{i \text { quantitiy prototype structure }}$

In the proposed solution, the scaled model strains must be identical to the prototype model strains. To this effect, the scale factor for strains as-computed based on the applied load and Young's modulus can be expressed as the following equation:

$$
\left(\frac{\sigma}{E}\right)_{\mathrm{p}}=\left(\frac{\sigma}{E}\right)_{\mathrm{m}} .
$$

where $\sigma$ and $E$ are respectively normal stress and Young's modulus of materials, $\mathrm{p}$ and $\mathrm{m}$ subscripts are the prototype and scale model, respectively.

The floor plan Axis $\alpha$ in Fig. 1 is selected for analysis. The test specimens were designed as one-thirdscale models of the three-story building [28]. The model was designed according to the quasi-static conditions listed in Tab. 1.

Table 1 Similarities between the model and prototype

\begin{tabular}{|c|c|c|}
\hline $\begin{array}{c}\text { Related physical } \\
\text { proper }\end{array}$ & Physical Parameter & Similarity \\
\hline \multirow{5}{*}{ Geometric } & Length & $1 / 3$ \\
\hline & Linear displacement & $1 / 3$ \\
\hline & Acreage & $1 / 9$ \\
\hline & Angular displacement & 1 \\
\hline & Strain & 1 \\
\hline \multirow{5}{*}{ Material } & Intensity & 1 \\
\hline & Modulus of Elasticity & 1 \\
\hline & Stress & 1 \\
\hline & Density & 1 \\
\hline & Mass & $1 / 3$ \\
\hline \multirow{6}{*}{ Load } & Acceleration of gravity & 1 \\
\hline & Concentrated load & $1 / 9$ \\
\hline & Line load & $1 / 3$ \\
\hline & Area load & 1 \\
\hline & Moment & $1 / 27$ \\
\hline & Shear force & $1 / 9$ \\
\hline Reinforcement & $\begin{array}{l}\text { Longitudinal reinforcement beam } \\
\text { and column }\end{array}$ & $1 / 9$ \\
\hline
\end{tabular}

The properties of the test specimens are listed in Tab. 2 and the dimensions and reinforcement details of the specimens are shown in Fig. 2. The geometry of the threestory framework is shown in Tab. 3, and the form of reinforcement is shown in Fig. 2. Two side columns in the frame were designed with corbels, in order to facilitate the installation of the load transfer jig.

Table 2 Type of specimen and purpose of experiment

\begin{tabular}{|l|l|l|}
\hline Specimen type & \multicolumn{1}{|c|}{ Form of framework } & \multicolumn{1}{|c|}{ Purpose of test } \\
\hline Specimen 1 & Third story of integral cast framework & Impact of seismic performance of simulated structure \\
\hline Specimen 2 & $\begin{array}{l}\text { First and second stories of integral cast framework, with third } \\
\text { story built by reinforced concrete }\end{array}$ & Simulation of the seismic performance of the frame after addition \\
\hline Specimen 3 & $\begin{array}{l}\text { First and second story of integral cast framework, with third story } \\
\text { built by lightweight steel }\end{array}$ & Seismic performance framework after addition \\
\hline
\end{tabular}

Table 3 Sample size table Unit: $\mathrm{m}$

\begin{tabular}{|c|c|c|c|c|c|c|c|c|c|}
\hline \multirow{3}{*}{ Specimen type } & \multicolumn{3}{|c|}{ Specimen 1} & \multicolumn{3}{|c|}{ Specimen 2} & \multicolumn{3}{|c|}{ Specimen 3} \\
\hline & \multicolumn{2}{|c|}{ Beam length } & \multirow{2}{*}{$\begin{array}{c}\text { Column } \\
\text { height }\end{array}$} & \multicolumn{2}{|c|}{ Beam length } & \multirow{2}{*}{$\begin{array}{l}\text { Column } \\
\text { height }\end{array}$} & \multicolumn{2}{|c|}{ Beam length } & \multirow{2}{*}{$\begin{array}{c}\text { Column } \\
\text { height }\end{array}$} \\
\hline & KL1 & KL2 & & KL1 & KL2 & & KL1 & KL2 & \\
\hline Framework of adding-storey one & 1,6 & 0,7 & 1,1 & 1,6 & 0,7 & 1,1 & 1,6 & 0,7 & 1,1 \\
\hline Framework of adding-storey two & 1,6 & 0,7 & 1,0 & 1,6 & 0,7 & 1,0 & 1,6 & 0,7 & 1,0 \\
\hline Framework of adding-storey three & 1,6 & 0,7 & 1,0 & 1,6 & 0,7 & 1,0 & 1,6 & 0,7 & 1,0 \\
\hline
\end{tabular}

The grade beam is connected to the frame column. The grade beam is $400 \mathrm{~mm}$ high, and its rigidity is sufficient for embedding in the solid boundary, necessary for accurate simulation of the framework's column foot. The beams on both sides of the mouth of the reserve cup protrude $250 \mathrm{~mm}$. To prevent the specimen from toppling over during loading; specific dimensions are controlled to reinforce the grade beam, as shown in Fig. 3.

This test takes place at the specific drilling position on the top of the second story column where reinforcing bar is planted, as shown in Fig. 4.

The drilling process did not damage the beam longitudinal reinforcement, but did weaken the column stirrups. The diameter of the HRB400 longitudinal reinforcement as-planted was $10 \mathrm{~mm}$. Previous research has worked with planting reinforcing bar comprised of inorganic anchoring materials, with implantation depth of longitudinal reinforcement at $15 \mathrm{~d}$, which meets standard requirements - in an actual construction situation, however, it is difficult to prepare the bar hole, and an actual anchoring depth around $20 \mathrm{~d},(200 \mathrm{~mm})$ is more appropriate. According to research standards of planting reinforcing bar comprised of inorganic anchoring material, bar whole diameter should be larger than the planted bar diameter by $4 \div 8 \mathrm{~mm}$ to achieve the best bonding results. In order to ensure bond quality, the hole must be minimized as much as possible. In this case, the planting reinforcing bar diameter was $14 \mathrm{~mm}$. 

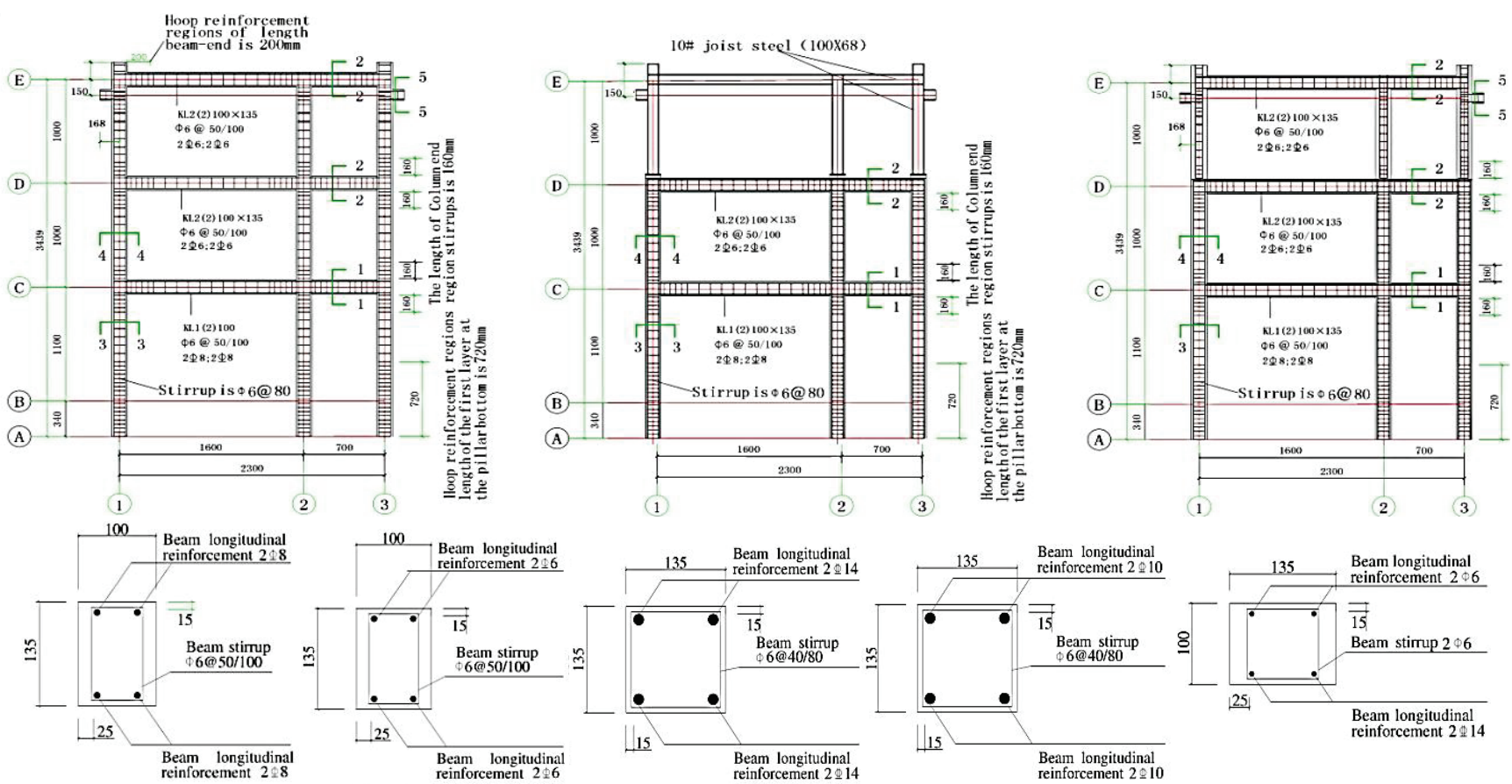

1-1 Section details

2-2 Section details

3-3 Section details 4-4 Section details

5-5 Section details

Figure 2 Specimen reinforcement drawing

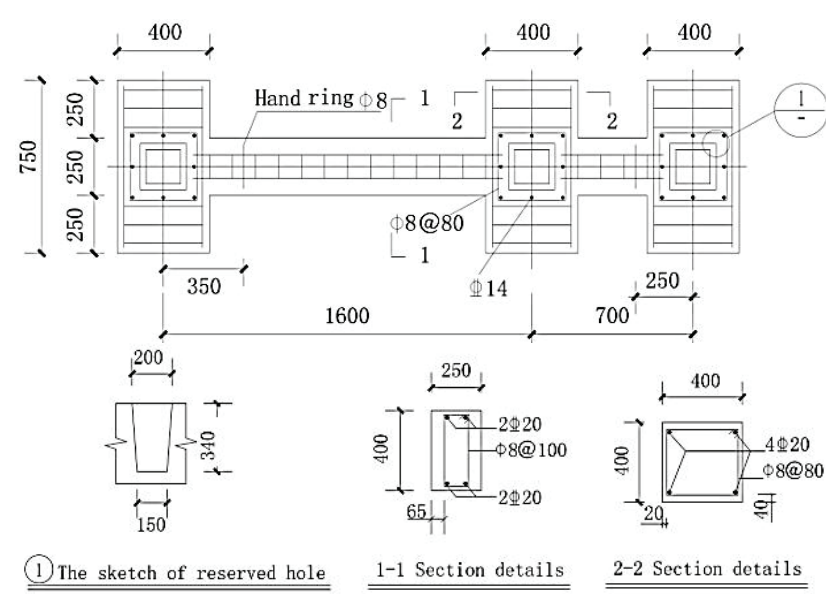

Figure 3 Figure of ground beam reinforcement

Light steel story-adding requires the planting of the steel plus welded gusset plates. Inorganic binder anchors the gusset plates and concrete together to ensure effective transfer of shear. A diagram of planting reinforcing bar via plug welds and gusset plates, with light steel columns with gusset plates, is shown in Fig. 4.
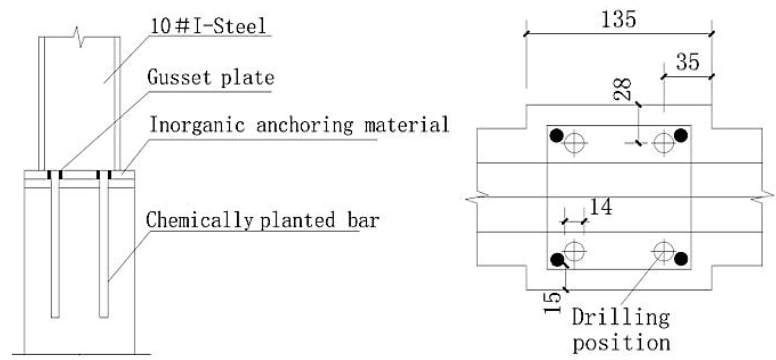

Figure 4 Connection diagram of the steel planting reinforcing bar adding-storey planting reinforcing bar and position of drilling

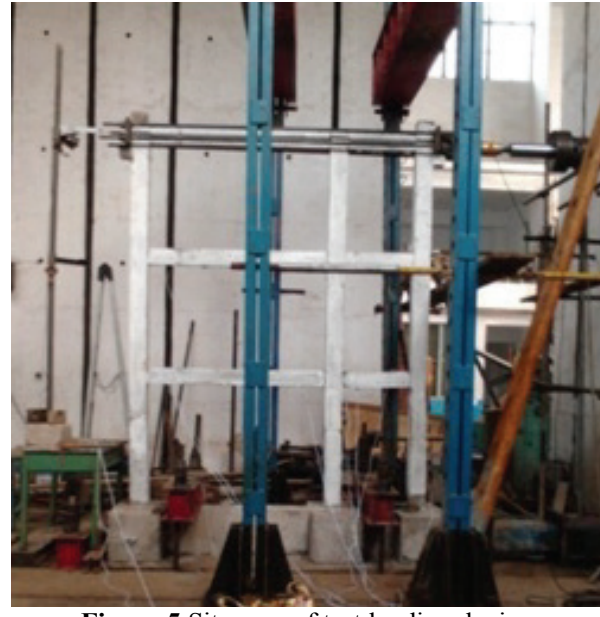

Figure 5 Site map of test loading device

\subsection{Testing equipment}

Because this test simulates an actual three-story reinforced concrete frame structure, there was no need to apply an axial force on the top of pillar to simulate the vertical load of an upper structure. The beam frame model consists of two steel, anchor-fixed static pedestals that provide the reaction force of the loading process. Horizontal, reciprocal load tension and compression through $100 \mathrm{t}$ hydraulic jack provided two-way, threelevel loading points for the beam frame. A horizontal hydraulic jack was fixed on the wall vertically, assisted by the temporary erection of scaffolding gravity loads which ensured the loading direction of the applied material as horizontal. For successful two-way loading, four $2,8 \mathrm{~m}$ long steel screw clamps were fixed to the load according to the position of each steel screw. The screws are $30 \mathrm{~mm}$ in diameter. The testing process ignored steel screw axial deformation, and the actual installation with complete loading is shown in Fig. 6. 


\subsection{Measurement of experimental observations}

During testing, cracks in reinforced concrete frame were observed and their position, order, and direction noted. The formation of plastic hinges was recorded, and a detailed description of experimental phenomena was made. The specific arrangement of the data acquisition and recording instruments follows.

(1) Horizontal load

Horizontal tension and compression on the bidirectional hydraulic jack was applied appropriately, plus the pressure sensor, which monitored horizontal force of the framework in real-time.

(2) Displacement monitoring

Displacement meters were arranged at the end of the first, second, and third story additions. The first beam displacement measurement range was taken at $\pm 50 \mathrm{~mm}$, the second beam displacement measurement was \pm 100 $\mathrm{mm}$, and the third was $\pm 150 \mathrm{~mm}$.

(3) Steel strain

The test model is designed to simulate strong shear, and weak bending. The test model must be consistent with the prototype structure, but after testing the model scale, certain unavoidable differences are accounted for. If using the same stirrup ratio, for example, the stirrup spacing exceeds $200 \mathrm{~mm}$, and the cross-sectional size of the part does not meet the requirements for power transmission. Therefore, the reinforced concrete frame had the column stirrup spacing of $80 \mathrm{~mm}$, spacing encrypted area of $40 \mathrm{~mm}$, frame beam stirrups spaced $100 \mathrm{~mm}$, and encrypted area spaced $50 \mathrm{~mm}$.

Both the bottom of the column longitudinal reinforcement and the longitudinal reinforcement on the second floor in the frame column possess greater force than other parts, so reinforced strain gauges were attached in these locations. Each monitoring location had two diagonally-arranged strain gauges. Each end of the frame beam across all trials was likely to be strained during loading of the plastic hinge, so all were monitored at the longitudinal reinforcement beam's end position. Again, each monitoring location had two diagonal strain gauges.

(4) Concrete strain

The principles at work for concrete monitoring are similar to steel. The main difference is that the bottoms of all columns in the first and second floor were set to monitor the position of the beam, where all monitoring locations measured concrete strain. A DH3818 data collector acquisition test was used to measure applied load and displacement of the measuring points, and a YE2533 data collector was used to gather information for the reinforced concrete strain gauges and strain monitors.

\subsection{Quasi-static tests on seismic performance of story- adding frame structures}

Quasi-static testing (QST) is currently, and will likely remain, the most common testing technique in earthquake-resistant structural engineering. Quasi-static tests indicate whether loads are applied at rates slow enough to reduce the effects of material strain. Much current knowledge about the seismic performance of structures, structural components, and their connections has been derived from quasi-static testing [29 $\div 32]$. From an informal survey of articles appearing in major structural engineering journals over the past ten years, about $80 \%$ to $90 \%$ of the current experimental research in earthquake-resistant engineering in China falls within this category.

This study performed Quasi-static testing by applying the horizontal, reciprocal load at the centre of the third layer of framework. The test used a dual control system of load displacement in the reinforced concrete frame before yielding results. Loading control was used, where the load differential was $5 \mathrm{kN}$, and each grade of loading cycled just once. The results of the original test frame's longitudinal reinforcement provided the definition of the yield structure. Displacement control loading was then performed, where the loaded differential was $1 \times$ bigger than the yield displacement of the structure. Each load cycled three times. The displacement control loading phase then began. Once the specimen displacement exceeded the maximum carrying capacity corresponding to the displacement, and carrying capacity dropped to 85 $\%$ of its maximum, the test model was considered destroyed. The loading system is shown in Fig. 7.

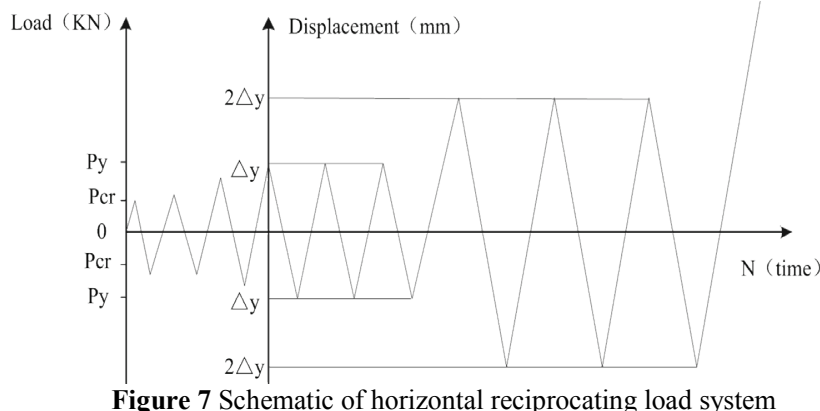

\subsection{Test results}

Concrete samples at the construction site were tested by natural curing 28 days after compression testing. The cubic compressive strength and axial compressive strength test results are shown in Tab. 4.

Table 4 Indicated measured values of mechanical properties of concrete

\begin{tabular}{|l|c|c|c|}
\hline Pouring order & $\begin{array}{c}\text { Grade } \\
\text { of concrete }\end{array}$ & $\begin{array}{c}\text { Cube } \\
\text { compressive } \\
\text { strength (MPa) }\end{array}$ & $\begin{array}{c}\text { Axial } \\
\text { compressive } \\
\text { strength (MPa) }\end{array}$ \\
\hline First pour & $\mathrm{C} 30$ & 33,67 & 21,92 \\
\hline Second pour & $\mathrm{C} 30$ & 32,81 & 21,45 \\
\hline
\end{tabular}

Note: Data in the table are averages of the test results of three concrete blocks, which have been multiplied by the cube compressive strength reduction factor of 0,95

The model specimen uses a total of five types of steel. Results are shown in Tab. 5.

Table 5 Measured values of the reinforced mechanical index

\begin{tabular}{|l|c|c|c|c|}
\hline $\begin{array}{c}\text { Type of } \\
\text { steel }\end{array}$ & $\begin{array}{c}\text { Steel } \\
\text { diameter } \\
(\mathrm{mm})\end{array}$ & $\begin{array}{c}\text { Yield } \\
\text { strength } \\
(\mathrm{MPa})\end{array}$ & $\begin{array}{c}\text { Ultimate } \\
\text { strength } \\
(\mathrm{MPa})\end{array}$ & $\begin{array}{c}\text { Elongation } \\
\text { rate (\%) }\end{array}$ \\
\hline HPB300 & 6 & 315,59 & 442,16 & 32,5 \\
\hline HPB300 & 8 & 322,75 & 452,89 & 32,5 \\
\hline HRB400 & 8 & 330,23 & 467,74 & 29,0 \\
\hline HRB400 & 10 & 337,41 & 490,20 & 30,0 \\
\hline HRB400 & 14 & 472,05 & 585,73 & 23,0 \\
\hline
\end{tabular}

Note: The data in the table are the average of the test results of all three test pieces of steel. 
Performance of inorganic anchoring material has a direct effect on the test results, so cement-based anchoring compressive strength tests were performed to ensure accuracy. The size of test cubes was $150 \times 150 \times 150$ mm. Results are shown in Tab. 6.

Table 6 Test results of cube compressive strength of cement-based

\begin{tabular}{|l|c|c|c|c|c|}
\hline \multicolumn{1}{|c|}{ Period } & $1 \mathrm{~d}$ & $2 \mathrm{~d}$ & $3 \mathrm{~d}$ & $7 \mathrm{~d}$ & $28 \mathrm{~d}$ \\
\hline $\begin{array}{l}\text { Compressive } \\
\text { strength (MPa) }\end{array}$ & 38,45 & 52,68 & 68,54 & 74,36 & 76,91 \\
\hline
\end{tabular}

Results show that the cement-based anchoring material in the test had strong mechanical characteristics. During the construction process, a small amount of expansion agent was added to the cement base anchoring material, allowing micro-volume expansion to improve bonding during the hardening process.

\section{Characteristics of damage \\ 4.1 Characteristics of damage of the integral cast reinforced concrete frame}

Framework of cast-in-place reinforced concrete is in the load control loading stage when the load reaches 10,5 $\mathrm{kN}$. Vertical cracks first appear in the beam end layer. When the load reaches $20 \mathrm{kN}$, the load displacement curve structure shows a clear inflection point. Once the structure begins yielding, shown at the beam end plastic hinge formation, the structure enters the plastic stage. In the displacement control loading stage, when the load reached $29,5 \mathrm{kN}$, the structure reaches maximum bearing capacity. At the beam end's plastic hinge, small cracks at the bottom of the column appear, and joint regions at the third and second layers show a few cross cracks. The structure's bearing capacity begins to decline when displacement reaches $80 \mathrm{~mm}$, where the joint in the third layer of the beam end and the joint region show quite serious concrete fragmentation, accompanied by concrete off phenomenon. At this point, in order to ensure safety during installation and disassembly, loading is halted. The column bottom is formed of plastic hinges.

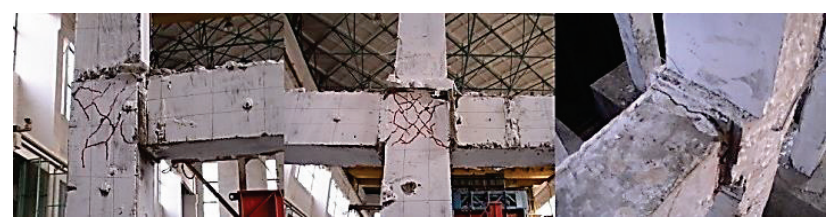

(a) Destruction of the first layer of the integral cast frame

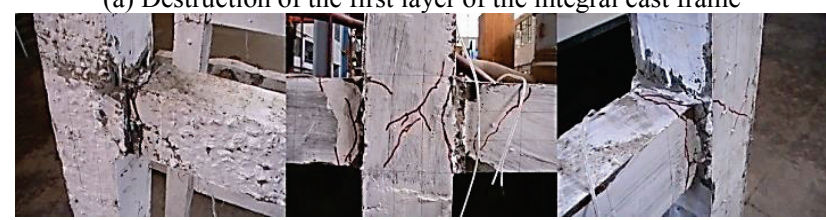

(b) Destruction of the second layer of the integral cast frame

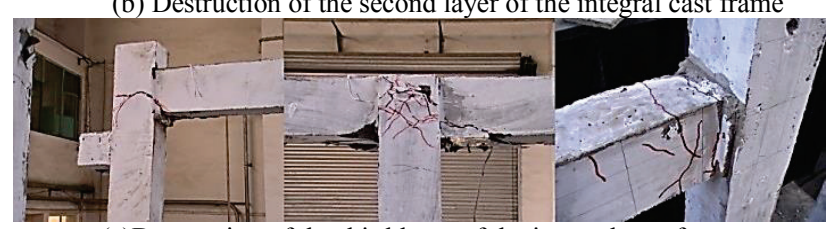

(c)Destruction of the third layer of the integral cast frame

Figure 8 Partial destruction of integral cast frame

After integral cast specimens are destroyed, the middle joint of the third layer shows more cross diagonal cracks. There is partial loss of concrete, and only a small number of other joints in the area with small cracks show concrete loss, so it is considered to have favourable integrity overall. The structure is in line with the seismic design requirements of strong joints and weak members. The column at the end of the second layer is relatively complete, without obvious cracks. The first layer of the lateral column bottom has some small cracks, but no significant concrete crushing. Before the plastic hinge is formed at the first layer at the bottom of the column, the majority of plastic hinges at end of the beam have failed. Partial destruction of the integral cast frame shape is shown in Fig. 8.

\subsection{Characteristics of damage of the added steel frame}

The steel framework story-adding specimen showed some vertical cracks in the beam end of the first layer. The cracking load of the structure was $14,04 \mathrm{kN}$. When the horizontal load reached $30,09 \mathrm{kN}$ and the top horizontal displacement reached $36,18 \mathrm{~mm}$, the majority of the steel specimen steel had entered the yield stage. There was a clear turning point in the skeleton curve, where the structure is considered to have entered the plasticity stage. As the loading process continued, the beam end showed constantly increased vertical cracks and constant expansion of the column foot planted reinforcing bar joints was accompanied by diagonal shear cracks. When the horizontal load reached $33,11 \mathrm{kN}$ and the top horizontal displacement reached $65,03 \mathrm{~mm}$, the maximum carrying capacity of the structure was reached. At this point, most of the beam end formed a plastic hinge, and the planted reinforcing bar joint was also damaged after the carrying capacity of the structure began to decline. When the horizontal displacement of the top reached $90,03 \mathrm{~mm}$, the foot end of the beam and column width showed larger cracks, breaking of the concrete planted reinforcing bar joints grew relatively serious, and the overall structure began to tilt. For safety, loading must stop at this point.

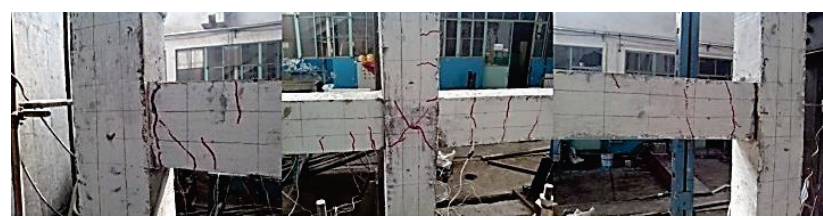

(a) Destruction of the first layer of the strut story-adding framework

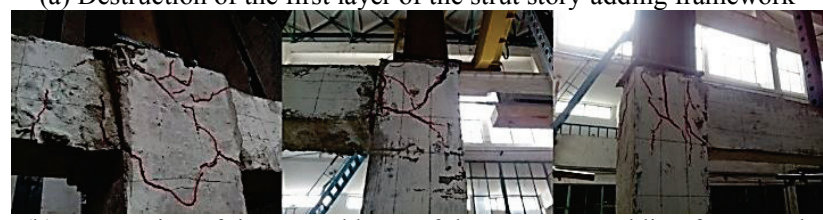

(b) Destruction of the second layer of the strut story-adding framework Figure 9 Partial destruction of strut story-adding framework

The entire testing process is detailed in Fig. 9. Cracks first appeared at the frame of the specimen in the bottom end of the beam. After the destruction of the specimen, the planted reinforcing bar joint of the second layer was seriously damaged, accompanied by the local concrete off phenomenon. The first layer showed only a few hairline cracks, no local concrete off phenomenon, had good overall integrity and integrity within the beam-column joints. The bottom layer of the second column was relatively intact, without obvious cracks. 
By comparing the destruction process of the integral cast reinforced concrete frame and reinforced steel frame story additions, the biggest difference is present in the extent of damage to the joint where the reinforcing bars are planted. The integral cast reinforced concrete frame full story joint degree is more favourable, and shows no further cross diagonal cracks. Layer joints in the reinforcing bar steel frame are subject to more of the damage, showing more cross diagonal cracks in the loading process. The maximum carrying capacity is similar for both frameworks; thus, though the planting reinforcing bar joints shows obvious damage, they still meet transfer load requirements.

\subsection{Characteristics of damage of the reinforced concrete frame specimen}

When the load reached 9,5 $\mathrm{kN}$ during the load control stage, some vertical cracks appeared at the end of the first layer of beam. When the load reached $18,5 \mathrm{kN}$, the loaddisplacement curve of the structure showed significant inflection points, and the structure was considered to have yielded the plastic hinge formation of the beam end, where the structure began to enter the plastic stage. In the displacement control load stage, once the load reached $29,5 \mathrm{kN}$, the structure reached its maximum capacity. At this time, most of the beam formed a plastic hinge end, small cracks appeared at the end of the structural column, a small amount of cross diagonal cracks appeared in the third layer joint region, and the second layer joint region showed more inclined cross cracks. The fragmentation of local concrete occurred due to damage caused by joint area stirrups, which lack capacity constraints, over the drilling process. The close pitch of drilled concrete also caused a significant amount of damage. The structure's carrying capacity started to decline once displacement reached $88 \mathrm{~mm}$, carrying capacity dropped to $25,0 \mathrm{kN} .85$ $\%$ of maximum load carrying capacity was reached, once the reverse load reached $88 \mathrm{~mm}$, and carrying capacity of the reinforcing bar frame dropped to $-23,5 \mathrm{kN}$. At this time, loading stopped to prevent excessive damage. When the bottom of the first-floor column was destroyed, a plastic hinge formed which combined old and new concrete surface dislocation.

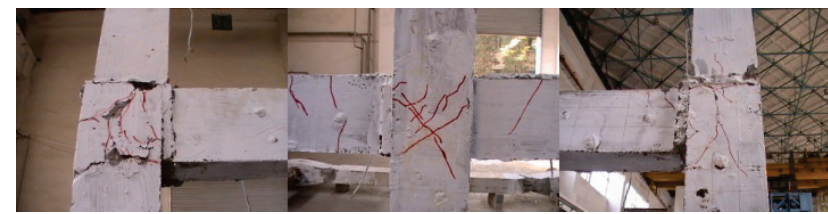

(a)Destruction of the first layer of the planted reinforcing bar frame

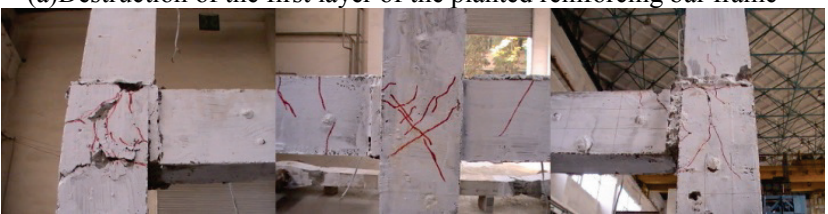

(b)Destruction of the second layer of the planted reinforcing bar frame

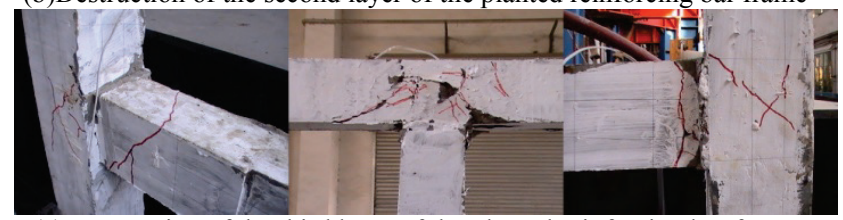

(c) Destruction of the third layer of the planted reinforcing bar frame Figure 10 Partial destruction of the planted reinforcing bar frame
After the destruction of the planted reinforcing bar frame, the destruction of joints in the third story became more serious. More cross diagonal cracks and partial concrete off phenomenon were present. The integral cast frame at the second layer also showed more cross diagonal cracks. The first layer joint region had only a few small cracks no local concrete off phenomenon, and maintained good integrity. The bottom layer of the second column was relatively intact, with no obvious cracks. The first layer of the lateral column at the end showed some small cracks, but no significant concrete crushing. Before the plastic hinge was formed in the end of the column at the first layer, each end of the beam that formed the plastic hinge showed obvious bean hinge failure. Partial destruction of this specific form of planted reinforcing bar frame is shown in Fig. 10.

The most significant difference between the destruction processes of the integral cast reinforced concrete frame and the reinforced steel frame story additions is the extent of damage to the joint where the reinforcing bars are planted. The integral cast reinforced concrete frame's joint performed better, showing fewer cross diagonal cracks; however, the layer joints of steel and concrete are subject to a larger extent of damages. More cross diagonal cracks formed during the loading process, because the maximum carrying capacity of either framework is similar. Although Planted reinforcing bar joints susceptible to damage, still meet transfer load requirements.

\section{Comparison and analysis of framework test results 5.1 Capacity, displacement and ductility}

Ductility refers to the magnitude of structural distortion that occurs when the framework is destroyed. Greater deformation indicates greater ductility. Ductility is comprised of two values: the ductility of individual components, and the ductility of the overall structure. As far as the overall structure at work in this study, accordance with seismic standards of ductility requires strong columns, weak beams, and stronger joints. As for individual components, it is known that steel has better ductility than concrete.

Ductility factors for cracking load, yield load, ultimate load, cracking displacement, yield displacement, ultimate displacement, destruction, and displacement in the three-story framework are shown in Tab. 7.

As shown in Tab. 7, the indicators for concrete poured framework and planted reinforcing bar frame are close to each other, indicating that the concrete planted reinforcing bar method of story addition meets necessary engineering requirements. General indicators for steel frame story addition are better than for concrete planted reinforcing bar, but steel frames show a lower ductility factor. Low ductility indicates lowered resistance to earthquake shock, which makes steel framework less favourable.

Currently, most countries make strict design specifications regarding the plastic properties of concrete structures. Required structural displacement ductility values vary between 3 and 5 [24], in order to ensure that structural components possess sufficiently high ductility. The ductility factor of the entire poured concrete framework is around 4, the ductility of planted reinforcing bar framework is between 3,826 and 3,995, and the ductility of steel framework is about $2,39 \div 2,03$, showing 
that planted reinforcing bar and light steel frameworks are sufficiently safe. After yielding, these structures show a strong deformation capacity, where the process of destruction occurs under ductile fracture.

Table 7 Ductility coefficient table of three-story framework

\begin{tabular}{|c|c|c|c|c|c|c|}
\hline \multirow{2}{*}{ Characteristics of frames } & \multicolumn{2}{|c|}{ Integral-cast frame } & \multicolumn{2}{|c|}{ Concrete story-adding frame } & \multicolumn{2}{|c|}{ Light steel story-adding frame } \\
\hline & Forward & Backward & Forward & Backward & Forward & Backward \\
\hline Cracking load $(\mathrm{kN})$ & 10,5 & $-11,0$ & 9,5 & $-10,0$ & 14,59 & $-14,27$ \\
\hline Yield load $(\mathrm{kN})$ & 20,0 & $-20,5$ & 18,5 & $-22,5$ & 30,09 & $-33,11$ \\
\hline Ultimate load $(\mathrm{kN})$ & 29,0 & $-29,5$ & 29,5 & $-27,5$ & 33,11 & $-32,56$ \\
\hline Failure load $(\mathrm{kN})$ & 28,0 & -29 & 25,0 & $-23,5$ & 28,8 & $-28,6$ \\
\hline Cracking displacement (mm) & 4,96 & 5,03 & 5,0 & 7,0 & 4,9 & 5,05 \\
\hline Yield displacement (mm) & 19,97 & 20,05 & 23,0 & 22,0 & 36,19 & 44,38 \\
\hline Ultimate displacement (mm) & 55,99 & 75,0 & 65,0 & 61,0 & 62,64 & 72,02 \\
\hline Failure displacement $(\mathrm{mm})$ & 80,2 & 80,22 & 88,0 & 87,0 & 86,54 & 90,0 \\
\hline Ductility coefficient & 3,857 & 4,100 & 3,826 & 3,955 & 2,39 & 2,03 \\
\hline
\end{tabular}

Ductile integral cast frames perform much better than entire frames of planted reinforcing bar, and planted reinforcing bar frames show superior ductility over light steel frames. The entire cast specimen's loaded bearing capacity drops to $85 \%$ when the reverse load carrying capacity reaches its maximum, closing the gap in ductility - but the integral cast frame is slightly more favourable than the planting reinforcing bar frame.

\subsection{Comparative analysis of plastic hinges}

According to the DH3818 data collection device, reinforced strain changes the value of data acquisition. The integral cast concrete frame specimens, planted reinforcing bar concrete frame, and concrete or light steel frame story additions respectively formed a plastic hinge, in order, as shown in Fig. 11.

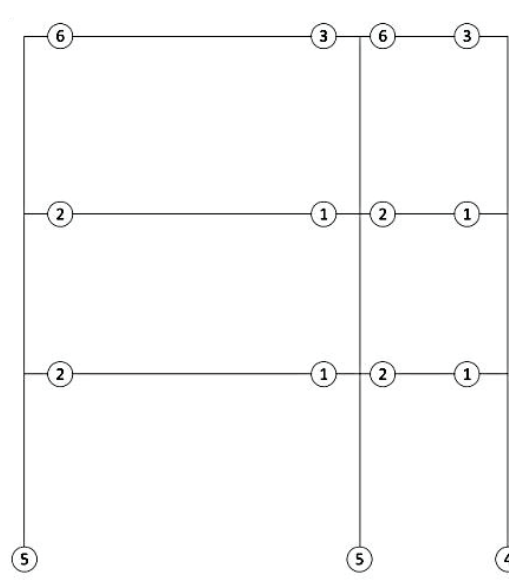

(a) Hinge order of the integral cast frame

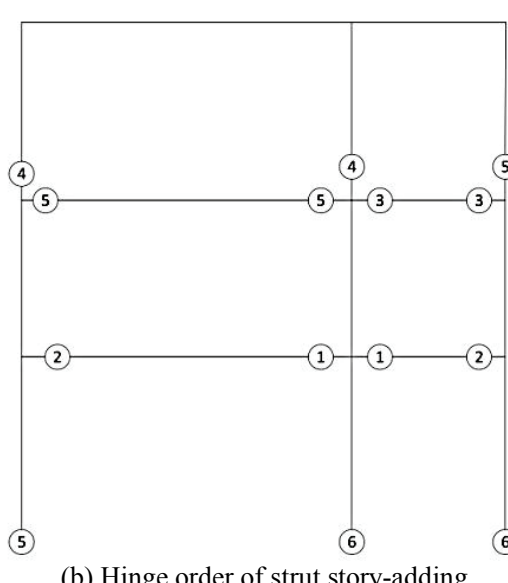

(b) Hinge order of strut story-adding framework

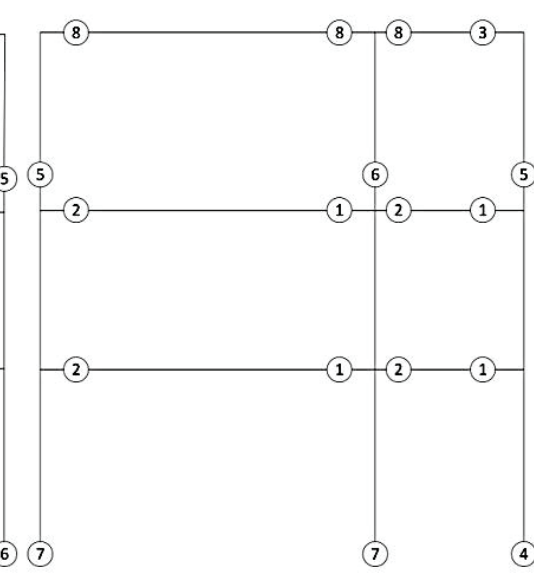

(c) Hinge order of the planted reinforcing bar frame

Figure 11 Comparison of the order of each specimen hinge

Fig. 11 shows that most of the beams end formed a plastic hinge during the formation of plastic hinges in the column. When the specimen was damaged, the integral cast frame column mostly maintained integrity, except the root formation of the plastic hinge pillar. There was no formation of plastic hinges during that time, so the frame was essentially a beam hinge failure mechanism, in line with the principle of strong columns and weak beams.

During testing, the first and second layer of concrete beam ends in the planted reinforcing bar frame formed the plastic hinge. Relatively dense joint cracks were observed, anywhere old and new concrete surfaces were combined began to dislocate, and the three-column bottom frame first formed the plastic hinge. After the bottom three-frame layer formed a plastic hinge, the majority of the beam end had formed a plastic hinge. The plastic hinge appeared first in the frame beams because the beam-column joints at the top of the second story were very dense, so the joint hole location was difficult to ascertain. The drilling of steel and concrete there caused more damage.

After the plastic hinge formed in the light steel frame, the connecting joints in the second layer on top of the frame showed more severe cracks. The bottom steel plate and the top of the concrete floor became dislocated, and the joint before the end of the beam partially formed the plastic hinge. This phenomenon occurred because the steel at the joints was not strong enough, and failed to reflect seismic-resistant design requirements of strong columns and weak beams. The damage pattern demonstrates that though simple, the steel story-addition method is substantially flawed.

\subsection{Comparative analysis of hysteretic characteristics}

Comparison between hysteretic curves of the integral cast reinforced concrete frame, the planted reinforcing bar story-adding frame, and the steel story-adding frame are shown in Fig. 12.

The shape of the hysteretic loop of the whole concrete poured frame, concrete planted reinforcing bar frame and concrete steel frame curves are mainly arched and anti-S. If there is an obvious "pinch" in the hysteretic curves, this indicates that reinforced slip has some influence on the two specimens. Before the specimen cracks, if the area surrounded by the hysteretic loop is small, then the specimen is basically in an elastic state. When the specimen yield increases with the displacement, 
the area surrounded by the hysteretic loop increases significantly. In the displacement control load phase, when the second cycle test pieces are lower than the slope of the first cycle, the slope of the third cycle is slightly lower than the second cycle, indicating that the stiffness of the frame levels as cycles decreases.

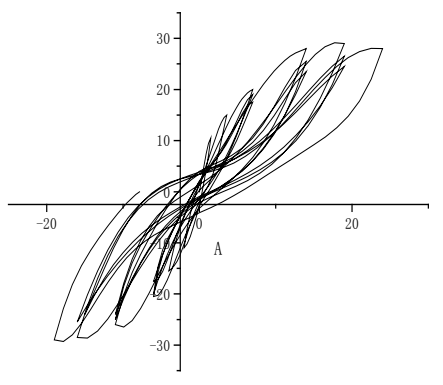

(a) integral casting frame

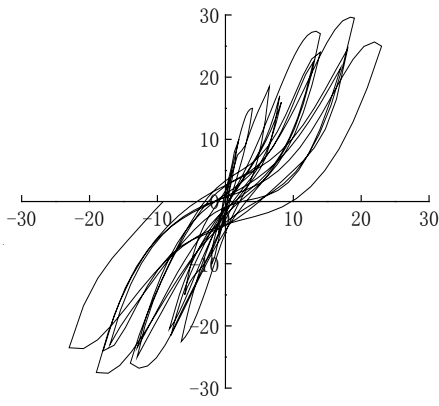

(b) concrete planted reinforcing barstoryadding framework

Figure 12 Hysteretic curve diagram

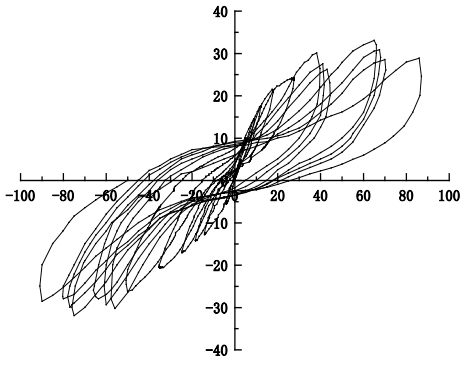

(c) steel story-adding framework
The main difference of specimen hysteretic curves is found where each structure reaches its maximum capacity. The integral cast of the specimen loaddisplacement curve flattens, and there is no obvious decrease in bearing capacity. The other two specimens show significant decrease in carrying capacity after the peak point, because formation of plastic hinges on the second story joint in the steel rebar planted reinforcing bar frame is close enough to the third story that its ability to manage the upper load decreases considerably. The hysteretic curves of concrete and steel story-adding components are closer to the anti- $Z$ type than the concrete planted reinforcing bar framework, indicating a relatively weak link anchor joint in the specimen.

\subsection{Comparative analysis of energy consumption}

Every cyclic loading forms a closed hysteretic loop of load-displacement curve, and the area enclosed by the hysteretic loop is the energy consumed by the specimen of the cycle. Therefore, the fuller the hysteretic loop is, the stronger the energy dissipation capacity of the specimen is. Viscous damping coefficients often use quantitative criteria to measure the energy dissipation capacity of a specimen [25]. The equivalent viscous damping coefficient is calculated as follows:

$h_{\mathrm{e}}=\frac{1}{2 \pi} \cdot \frac{S_{\mathrm{ABC}}+S_{\mathrm{ADC}}}{S_{\mathrm{OBE}}+S_{\mathrm{ODF}}}$,

where $h_{\mathrm{e}}$ represents the equivalent viscous damping coefficient, the triangle is the enclosed area of a hysteretic curve in Fig. 13, and the abscissa is area of the triangle in Fig. 13

The equivalent viscous damping coefficient as-tested is shown in Fig. 14.

(1) The integral cast framework is in the displacement control loading stage at four load levels. The equivalent viscous damping coefficients of the first cycle are 0,$07539 ; 0,08878 ; 0,08150$ and 0,09643 .

(2) The equivalent viscous damping coefficient of concrete planted reinforcing bar frame under the displacement control loading stage at the first cycle out of four load levels were 0,$08931 ; 0,08327 ; 0,07961$ and
0,08593. Compared to the overall framework for concrete pouring, the energy dissipation capacity is closer to the post-yield. Nearer to the destruction of load displacement, the whole framework of energy dissipation capacity for pouring is superior to planting reinforcing bar.

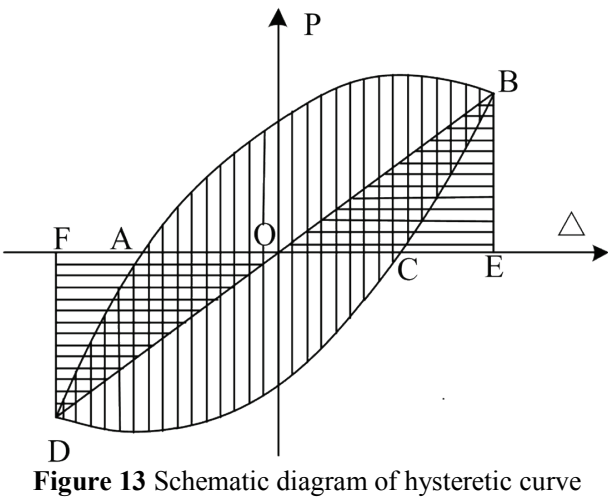

Equivalent viscous damping coefficient

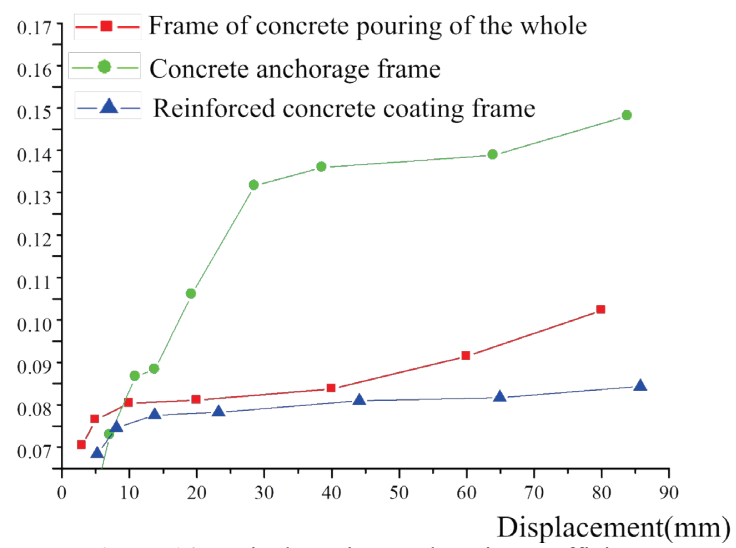

Figure 14 Equivalent viscous damping coefficients

(3) The concrete steel frame story addition in the displacement control loading stage had three load levels, where equivalent viscous damping coefficients in the first cycle were 0,$14101 ; 0,14390$ and 0,15312 . The energy dissipation capacity of the steel framework was demonstrated to be superior to the other frameworks studied. 


\subsection{Comparative analysis of stiffness degradation}

By drawing a curve for stiffness degradation, the effective stiffness of each framework can be obtained, expressed as follows:

$K=\frac{P}{\Delta}$,

where $P$ is the load value applied by the control point for each load level during the first cycle, and $\Delta$ corresponds to the displacement of $P$.

Comparison of stiffness of the integral cast frame and planted reinforcing bar frame degradation is shown in Fig. 15.
As shown in the comparison chart for stiffness degradation, the initial stiffness of the frame is slightly higher than the integral cast planted reinforcing bar frame. The frame is slightly higher in initial stiffness for the planted reinforcing bars of the steel frame, but with increase in displacement, the relative stiffness of all three frameworks starts to level out. The three frame specimens' stiffness degradation curves in both directions are not completely symmetrical, because the geometric forms of the frameworks are not equal. The loading direction is the primary cause of damage to any of the three frameworks.

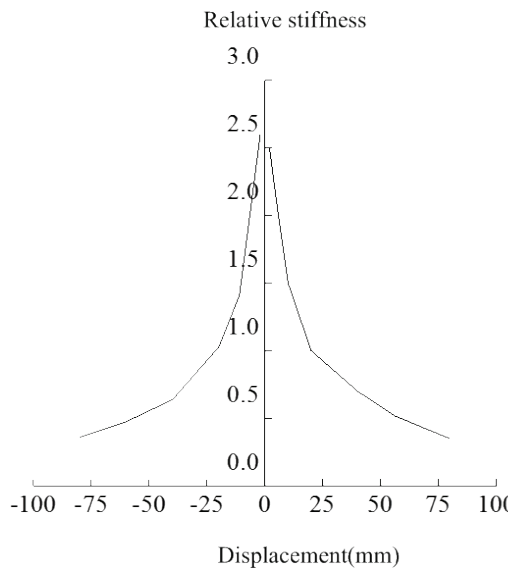

(a) Curve of stiffness degradation of all frames

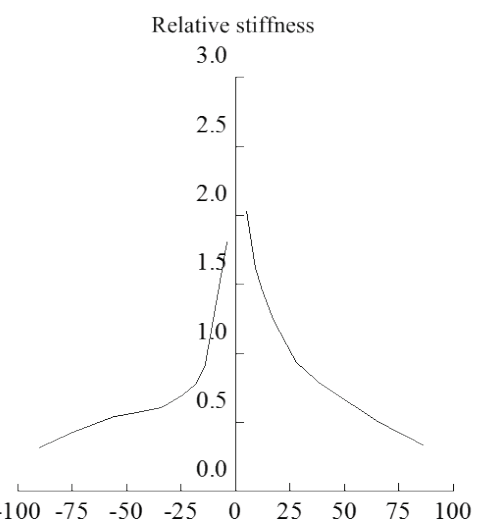

Displacement(mm)

(b) Curve of stiffness degradation of steel story-adding frame

Figure 15 Comparison chart of stiffness degradation of concrete structures

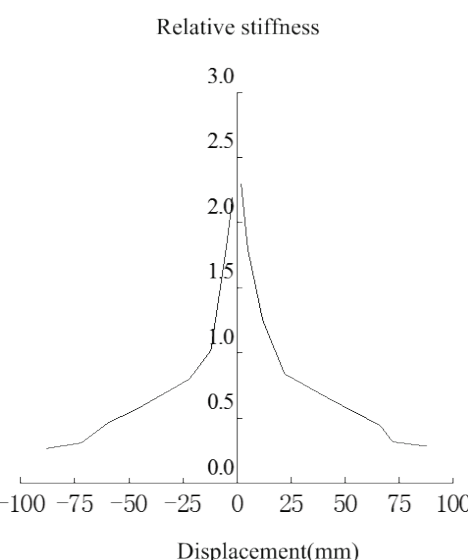

(c) Curve of stiffness degradation of the concrete planted reinforcing bar frame

\section{Conclusion}

The main results of quasi-static testing as performed on three specimens are presented and discussed below.

(1) The maximum carrying capacity of the integral cast concrete frame and the concrete planted reinforcing bar frame is essentially the same, as each framework is similarly columnar and concrete-based. Respective ductility values for each framework indicate steel possesses similar ductility to concrete, but that other advantages were indicated in the steel structure.

(2) The ductility factor of the entire concrete poured framework is around 4, and the ductility factor of the planted reinforcing bar framework was between 3,826 and 3,995. The ductility factor of the steel framework was between 2,39 and 2,03, indicating that the planted reinforcing bar framework, and light steel frame structures with a certain safety margin, show ductile failure after strong deformation begins. Planting reinforcing bars, however, causes less damage to the overall structure. Adding joints to the framework affects the total strength and ductility of the steel. The existing concrete frame story-adding procedure stresses vital capacity, stiffness, ductility, and other energy dissipation factors within the structure. The best combination of performance, plus the choice of framework and components, must account for the size and occurrence of ductile plastic hinge structure and act accordingly.
(3) Successful story addition requires conscious implementation of strong columns, weak beams, and stronger joints. This study found that the beam column hinge mechanism is the superior hinge mechanism, bending failure is better than shear failure, and large bias damage is better than small bias. Concrete planted reinforcing bar design is most effective when it accounts for longitudinal steel reinforcement ratio control, the control of axial compression ratio, and spacing methods. For successful, safe, and effective design of steel and concrete story additions, the connection joint control ductility and plastic hinge are of crucial consideration.

\section{References}

[1] Ai, Qi. Seismic Appraiser and Strengthening Masonry Buildings Transforming by Adding Storey. // Earthquake Engineering and Engineering Vibration. 24, 2(2004), pp. 114-116.

[2] Yang, Li. Application of light steel structure in adding layer construction of house. // Shanxi Architecture, 20, 1(2009), pp. 47-64.

[3] Lei, Honggang; Qin, Jiping. Research on the Possibility and Relative Problems of Structure Added by Light-weight Steel Storey. // Taiyuan University of Technology. 3, 4 (2001), pp. 58-75.

[4] Xiaopei, Zhang. Discussion on adding-story and renovation of housing. // Building Science Research of Sichuan. 3, (1994), pp. 33-35. 
[5] Yan, Wang; Jincheng, Li. The Study and Application of the Structure of Added Light Gauge Steel Stories. // Qingdao Institute of Architecture and Engineering. 3, (1998), pp. 4550 .

[6] Tao, Zhang. Integral Design and Seismic Resistant Property Analysis of the Adding Steel Stories on the Top of the Original Buildings, Ph.D. thesis, Tsinghua University, 2005.

[7] Feng, Song. The Technique of Adding Extra-floors Spanning Existing Building with Steel Structure and Its Application, master degree thesis, Tsinghua University, 2005.

[8] Peicheng, Wu. The Study of a Seismic Design Method of Structure Raised by Some Light-gauge Steel Stories, Master degree thesis, Lanzhou University of Technology, 2006.

[9] Zhang, Qi. Seismic Appraiser of Adding Storey. // Earthquake Engineering and Engineering Vibration. 1, 12 (2000), pp. 85-88.

[10] Wang, H. Z. Discussion about the House Design Standard of Adding Storey in Earthquake Zones. // Engineering Seismology. 17, 12(2000), pp. 23-28.

[11] Zhaohui, (Joey) Yang. Numerical analysis of permafrost effects on the seismic site response. // Soil Dynamics and Earthquake Engineering. 31, (2011), pp. 282-290. DOl: 10.1016/j.soildyn.2010.08.004

[12] Huihui, Yuan. Experimental study of the seismic behavior of partially concrete-filled steel bridge piers under bidirectional dynamic loading. // Earthquake Engng Struct. Dyn. 42, (2013), pp. 2197-2216. DOI: 10.1002/eqe.2320

[13] Hong, M. A.; Jun, D. Application and Development of Light-Gauge Steel in Story-Adding Structures of Old Buildings. // Journal of Nunjing Architectural and Civil Engineering Institute. 58, 3(2001), pp. 66-71.

[14] Zhang, X. F. Anti-seismic analysis of buckling restraining brace supported light-weight steel frames for building reconstruction with storely-adding. // Journal of Lanzhou University of Technology. 36, 3(2010), pp. 118-121.

[15] Ni, Xiu-guo. Experimental Study of the Seismic Behavior for Chemically Planted-bar Joints under Reversed Cyclic Lateral Loads, master degree thesis, Hefei University of Technology, 2005

[16] Wang, Ting-ting. Bonding Performance Study of Inorganic chemistry Bonder Rebar on Concrete Structure, master degree thesis, University of Jinan, 2012

[17] Peng, Xiao-qin; Liu, Yan-mend; Zhong, An-xin; Yang, Qiao. Experimental Research on High-strength Inorganic Anchoring Material. // Journal of Chongqing Jianzhu University. 29, 2(2007), pp. 113-115.

[18] Cook, R. A. Behavior of chemical bonded anchors. // Journal of Structural Engineering. 119, 9(1993), pp. 27442762. DOI: 10.1061/(ASCE)0733-9445(1993)119:9(2744)

[19] Mcvay, M.; Cook, R. A.; Krishnamurthy, K. Pull-out simulation of post-installed chemically-bonded anchors. // Journal of Structural Engineering. 122, 9 (1996), pp. 10161024. DOI: 10.1061/(ASCE)0733-9445(1996)122:9(1016)

[20] Cook, R. A.; Kunz, J.; Fuchs, W.; Konz, R. Behavior and design of single adhesive anchors under tensile load in uncracked concrete. // ACI Structural Journal. 95, 1(1998), pp. 9-26.

[21] Higgins, C. C.; Klingner, R. E. Effects of environmental exposure on the performance of cast-in-place and ret-rofit anchors in concrete. // ACI Structural Journal. 955, (1998), pp. 506-517.

[22] Cook, R. A.; Konz, R. C. Factor's influencing bond strength of adhesive anchors. // ACI Structural Journa. 98, 1(2001), pp. 76-86.

[23] Zhang, Jianrong; Wu, Jin; Yang, Jianhua. Experimental research on the behavior of concrete beams with adhesive reinforcement under static and fatigue bending loads. // Journal of Building Structures. 26, 5(2005), pp. 96-103.
[24] Wood, D. M. Geotechnical modeling. Oxford shire: Spoon Press, 2004. DOI: 10.4324/9780203477977

[25] Shaughnessy, E. J.; Katz, I. M.; Schaffer, J. P. Introduction to fluid mechanics. Oxford, Oxford University Press, 2005.

[26] Buckingham, E. On physically systems: illustrations of the use of dimensional equations. // Phys Rev. 4, 4(1914), pp. 345-376. DOI: 10.1103/PhysRev.4.345

[27] Lord Rayleigh; Strutt, J. W. The principle of similitude. // Nature. 96, 2406(1915), pp. 396-397. DOI: 10.1038/096396d0

[28] China Academy of Building Research. JGJ 101-96 Specification of testing methods for earthquake resistant building, Beijin, Institute of the ministry of construction standard quota, 1997.

[29] Karsan, I. D.; Jirsa, J. O. Behavior of Concrete under Compressive Loadings. // Journal of the Structural Division. 95, 12(1969), pp. 2543-2563.

[30] EERI. Experimental Needs for Improving EarthquakeResistant Design of Buildings. // Report, EERI, Berkeley, CA, 84, 1(1984), pp. 43-46.

[31] Laefer, D. F. et al. The manufacturing, assembly, and testing of scaled, historic masonry for one-gravity, pseudostatic, soil-structure experiments. // Construction and Building Materials. 25, 12(2011), pp. 4362-4373. DOI: 10.1016/j.conbuildmat.2011.03.066

[32] Leon, R. T.; Deierlein, G. G. Considerations for the Use of Quasi-Static Testing. // Earthquake Spectra. 12, 1(1996), pp. 87-109. DOI: 10.1193/1.1585869

\section{Authors' addresses}

\section{Ding Hongyan, Professor}

1) State Key Laboratory of Hydraulic Engineering Simulation and Safety, Tianjin University, Tianjin 300072, China

2) Key Laboratory of Coast Civil Structure Safety (Tianjin

University), Ministry of Education, Tianjin 300072, China

3) School of Civil Engineering, Tianjin University, Tianjin 300072 , China

Guo Yaohua,

School of Civil Engineering, Tianjin University, Tianjin 300072, China

Du Chuang, Corresponding author

1) School of Civil Engineering, Tianjin University, Tianjin 300072 China

2) College of Civil Engineering, Hebei University of Technology,

Tianjin 300401, China

E-mail: duch_1@sina.com

Zhang Lei

School of Civil Engineering, Tianjin University, Tianjin 300072, China

Zhang Puyang, Associate Professor (Corresponding author)

1) State Key Laboratory of Hydraulic Engineering Simulation and Safety, Tianjin University, Tianjin 300072, China

2) Key Laboratory of Coast Civil Structure Safety (Tianjin

University), Ministry of Education, Tianjin 300072, China

3) School of Civil Engineering, Tianjin University, Tianjin 300072 , China

E-mail: zpy_td@163.com 